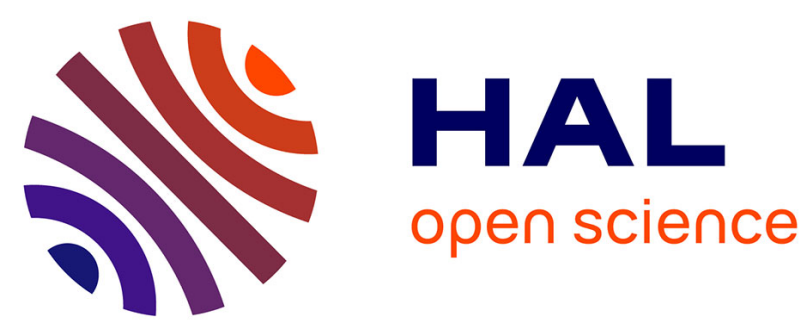

\title{
An analysis of the seismic activity of Popocatepetl volcano, Mexico, associated with the eruptive period of December 2002 to February 2003: looking for precursors
} Aida Quezada-Reyes, Philippe Lesage, C. Valdés-González, Laurence Perrier

\section{- To cite this version:}

Aida Quezada-Reyes, Philippe Lesage, C. Valdés-González, Laurence Perrier. An analysis of the seismic activity of Popocatepetl volcano, Mexico, associated with the eruptive period of December 2002 to February 2003: looking for precursors. Geological Society of America Special Papers, 2013, 498, pp.89-106. 10.1130/2013.2498(06) . hal-01021899

\section{HAL Id: hal-01021899 \\ https: / hal.univ-grenoble-alpes.fr/hal-01021899}

Submitted on 9 Jul 2014

HAL is a multi-disciplinary open access archive for the deposit and dissemination of scientific research documents, whether they are published or not. The documents may come from teaching and research institutions in France or abroad, or from public or private research centers.
L'archive ouverte pluridisciplinaire HAL, est destinée au dépôt et à la diffusion de documents scientifiques de niveau recherche, publiés ou non, émanant des établissements d'enseignement et de recherche français ou étrangers, des laboratoires publics ou privés. 


\section{An analysis of the seismic activity of Popocatepetl volcano, Mexico, associated with}

the eruptive period of December 2002 to February 2003: looking for precursors.

${ }_{1}$ Dept. of Earth and Environmental Science, New Mexico Institute of Mining and

6 Technology, Socorro, NM 87801

${ }^{2}$ Servicio Sismológico Nacional, Instituto de Geofísica, Universidad Nacional Autónoma

${ }^{3}$ ISTerre, CNRS, IRD : R 219, Université de Savoie, 73376 Le Bourget-du-Lac, France

\section{ABSTRACT}

Since it reactivated in 1994, Popocatépetl volcano has undergone cycles of formation and destruction of several lava domes. This surface activity is generally associated with increasing seismic activity before the explosions that destroy the domes. A comprehensive analysis of seismic records from November 2002 to February 2003 is carried out in order to identify precursors of a series of explosive events. Daily numbers of volcano-tectonic earthquakes and long-period events, as well as daily tremor duration, are obtained. Spectral features of the LP events and tremor are also calculated and high-frequency precursory signals of the LPs are studied. No clear variations of these characteristics of the seismicity can be detected before the eruptions. RSAM calculations show that, besides small fluctuations related to the explosions, the rate of seismic energy released is quite stable during the studied period. Minor short-lived variations of RSAM levels are observed before only five of eighteen eruptions, with no accelerating release of energy. It is thus quite difficult to identify reliable seismic precursors during the eruptive sequence. This situation is probably related to the open state of the system and has important implications on future risk assessment regarding this volcano.

Keywords: Popocatépetl volcano, volcano seismology, volcanic tremor, long period event, explosion quake, precursor

\section{INTRODUCTION}

Popocatépetl is a Quaternary andesitic stratovolcano located $65 \mathrm{~km}$ from Mexico City in the Trans-Mexican Volcanic Belt. A large volcanic eruption originating from this volcano could potentially affect more than 40 million people living in the states of Mexico, Puebla and Morelos and could greatly affect the country's economy. Popocatépetl volcano has undergone several eruptive phases, seven of which comprise Plinian eruptions that produced extensive deposits from pyroclastic flows, pumice falls and lahars (C. Siebe et al., 1995). The most recent Plinian phase occurred $\sim 30,000-50,000$ years ago. Minor magnitude explosive activity has been documented in pre-Hispanic Colonial chronicles and Mexican codices (Aztec manuscript paintings), such as Vatican A and Telleriano-Remensis

41 (De la Cruz-Reyna, et al., 1995). From 1720 to 1919 the volcano had a period of relative 
quiescence. During the first half of the 1920's a new explosive phase (1919 - 1927), characterized by ash-rich columns (Macías and Siebe, 2005), modified the morphology of the inner crater. This explosive activity was observed by Murillo (1939) and reported by Waitz, (1921) and (Camacho, 1925). Since it re-awoke on December 21, 1994, Popocatepetl's activity has consisted mainly of cycles of extrusion and destruction of lava domes. On June 30, 1997, an $8 \mathrm{~km}$ high eruption cloud produced ash fall on Mexico City and forced the airport to close for several hours (Valdés et al., 2002). Large eruptions were recorded on April 23, 1999 and from December 11 to January 23, 2000 with a Volcanic Explosive Index (VEI) of 2 - 3, and 2, respectively (Novelo-Casanova and ValdésGonzález, 2008). On January 22, 2001 a VEI 3-4 eruption generated a 1-km-high cloud, mud flows on the northern flank of the volcano and pyroclastic flows that reached up to 6 $\mathrm{km}$ from the crater (Martin-Del Pozzo et al., 2003). Small to moderate explosions have also been reported by the Centro Nacional de Prevención de Desastres (CENAPRED) in 2002, 2003, 2005 and in late 2006 (Glob. Volcan. Netw. Bull, 2002a; 2002b; 2003a; 2003b; 2005; 2006).

Since its reactivation in 1994, Popocatépetl volcano has produced several tens of daily long-period (LP) events that have been classified into different families based on distinctive waveform features and frequency range (De la Rosa et al., 2003; Arciniega-Ceballos et al., 2008). Volcano-tectonic events (VT), although scarce, have been associated with magma intrusion during dome-growth phases and to local and regional stresses (Lermo et al., 1996; 2006; Martinez-Bringas, 2006; Arámbula-Mendoza, 2007; Arámbula-Mendoza et al., 2010; De la Cruz-Reyna et al., 2008). Sustained tremor, as well as intermittent tremor episodes, have been observed during several eruptive phases over the past eighteen years (Arámbula-Mendoza, 2002; Arciniega-Ceballos et al., 2003).

Nearly every eruption is preceded by an increase in earthquake activity along with other precursory phenomena such as tilt, fault development and high concentrations of several chemical species. This has been observed to be the case with several active volcanoes such as Mt. St. Helens (Swanson et al., 1985), Redoubt (USA) (Brantley, 1990), Kelut (Indonesia) (Lesage and Surono, 1995), Merapi (Indonesia) (Voight et al., 2000), Colima Volcano (De la Cruz-Reyna and Reyes-Dávila, 2001) and many others. A significant rise of seismic and fumarolic activity was registered on Popocatépetl in 1993 but did not lead to an eruption (Glob. Volcan. Netw. Bull., 2002a, 2002b, 2003a, 2003b, 2005, 2006). Another period of increased activity started on October 1994 and culminated two months later with a series of explosions on December 21, 1994 (De la Cruz-Reyna, et al., 2008). The eruption of June 30, 1997 was also preceded by a series of VT events with magnitudes of 2.0 to 2.7 and volcanic tremor marked the onset of the explosive activity. On November 22, 1998 a rise in number of LP events and tremor episodes per day was recorded. Seismicity increased again on November 23 and harmonic tremor was recorded the next day. An intense eruptive episode that generated up to 4-km high clouds occurred from November 25 to 30, 1998 (Valdés et al., 2002). On September 2000 a series of VT events below the crater were recorded. Degassing lasted up to 30 minutes and harmonic tremor was observed in the coda (Valdés et al., 2002). 
In contrast with these well-documented eruptive episodes that were preceded by increased seismic activity, little attention has been paid to explosive phases with no clear precursory seismicity. In this work we present a detailed analysis of the seismicity related to a series of 18 explosions observed in December 2002 and February 2003. In this period, a temporary seismic network including several small-aperture arrays complemented the Popocatépetl's permanent network. We identify tenuous precursory phenomena for some of the largest explosions while most of them occurred without any precursor. The lack or the weakness of precursory seismicity prior to the 18 explosive events during this period represents an uncommon situation at Popocatépetl volcano and could be associated with an open-conduit stage during a recharge phase that involves the formation of a dome and its subsequent destruction. The 2002-2003 explosive phase is anomalous at Popocatépetl and of great importance as it provides new insight on the diverse activity of this volcano. These observations should be considered in Popocatépetl's future eruptive behavior.

\section{SEISMIC NETWORKS}

Popocatépetl volcano's permanent seismic network comprises seven stations with threecomponent short-period $(1 \mathrm{~Hz})$ seismometers (Fig.1). This network is continuously recording at 100 sps and all signals are transmitted by telemetry to the central recording facility at CENAPRED (National Disaster Prevention Center) in Mexico City. Two of these stations, Canario (PPP) and Chipiquixtle (PPX), located at 2 and $3.7 \mathrm{~km}$ from the crater respectively also have a Guralp CMG 40T-30 s broadband seismometer.

In October 2002, a temporary network was deployed at Popocatépetl volcano. The study was carried out in the framework of a cooperative project including the Université de Savoie, France, the Institute de Recherche pour le Developpement (IRD), France, and the Institute of Geophysics at UNAM, Mexico. The equipment consisted of nine Guralp CMG 40T (seven $30 \mathrm{~s}$ and two $60 \mathrm{~s}$ ) broadband seismometers. They covered a distance range of 2 - $14 \mathrm{~km}$ from the vent and were located at elevations between 2500 and $4300 \mathrm{~m}$ asl (Fig. 1). Signals were recorded at 100 sps in continuous mode until February 2003 by Reftek 72 02 Digital Acquisition Systems (DAS). Each station operated autonomously with solar panels and batteries. The sensors were placed on a tile in a 1-m-deep hole, covered with plastic bags, leveled and buried in sand to reduce temperature variations. In several places, small arrays of 3 short-period vertical seismometers with aperture of about $100 \mathrm{~m}$ were also set up (FPP, FPX, FCO) in order to measure slowness and back-azimuth and locate the source of emergent signals (Fig.1).

The technique used to determine the slowness vector, i.e. back-azimuth and apparent velocity, is based on the similarity of waveforms when the distances between sensors are small enough (e.g. Métaxian et al., 2002). The time delays between each pair of sensors are estimated using the cross-spectral method (Poupinet et al., 1984; Fréchet, 1985; Got et al., 1994) for successive time windows sliding along the seismograms. The time delay, which depends on the relative position of sensors, can be expressed as a function of the slowness vector. Consequently, the slowness vector can be calculated by linear inversion assuming that (1) the wave field is composed by non-dispersive plane waves, (2) only one wave 
propagates across the array or one is dominant at a given time and (3) the medium beneath the array is laterally homogenous. The direction of propagation of the wave field, for a given time window, can be estimated by calculating the probability density function (PDF) of the back-azimuth (Métaxian et al., 2002). If several seismic antennas are available, the different back-azimuth PDFs can be combined to compute the PDF of the position of the source (Métaxian et al., 2002). The maximum likelihood gives the source position of the seismic signal. Métaxian et al. (2002) showed that the greater the number of seismic arrays and the more evenly distributed around the volcano they are, the better the source position is constrained. Results from the data recorded at both seismic networks as well as source locations from explosive events are presented in section 3.3.

\section{SEISMIC ACTIVITY AT POPOCATÉPETL VOLCANO}

The reawakening of Popocatépetl volcano in December 1994 and subsequent eruptive episodes have been preceded by an energetic rise in seismicity characterized by: VT events, related to magmatic activity that generates stress changes and, as a consequence, brittle failure; LP events and tremor, associated to pressure transients in the fluid that induce the resonance of conduits or fluid-filled cracks (e.g. Chouet 1988). In this section, we present the evolution of the seismicity from January 2002 to March 2003, and October 2002 to February 2003. However, during this eruptive phase, no anomalous behavior in the seismicity prior to the eruptions of December 2002 and February 2003 was observed.

\subsection{Overview of the seismicity from January 2002 to March 2003}

From January 2002 to March 2003, seismicity at Popocatépetl volcano consisted mostly of LP, VT events, explosions and tremor episodes. The seismic activity in early and mid-2002 corresponds to the extrusion of the dome reported by CENAPRED in December 2001 and its partial destruction. The extrusion of recent material that formed a new dome and its destruction was observed from mid-2002 to early 2003.

A total of 8243 LP, 270 VT events and 36,050 minutes of volcanic tremor were recorded by the permanent seismic network during this 15-month period. Seven explosions occurred in February, April and May 2002 (all explosions are indicated with a vertical dashed line (Fig. 2). High occurrence of LP seismicity was observed from April 8 to May 30 with the highest peak of the year, 124 events, on May 13. Two days later, on May 15, 18 VTs were recorded. One VT event from this swarm reached a magnitude of M 3.7. LP activity remained high and two explosions occurred on May 18 and 22. The current dome reduced in size, suggesting it was partially destroyed by the activity reported on previous days. On May 29 (Fig. 2b), VT occurrence increased from 2 to 4 events per day and reached another peak on June 1, with a swarm of 14 events. VT activity averaged 4 events per day on June 11, 12, 17 and 27. LPs increased again on July 22: a total of 80 events were recorded and ash emission was also observed. High rates in LP seismicity, from August 11 to September 2, coincided with high VT activity on August 18 and September 1 and 4. This behavior may be related to a new dome reported by CENAPRED in early September. In addition, from August 29 to September 30, tremor episodes lasted between 480 to 1200 minutes per day (Fig. 2c). Moreover, on November 6, a strong degassing event occurred, followed by ash emission from November 22 to November 25. On November 24, an increment in LP 
204

events (78) was observed (Fig. 2a). Finally, LP activity decreased notably on December 14, four days prior to the first of 18 explosions that occurred between December 2002 and February 2003 and will be discussed later.

\subsection{Analysis of seismic events from October 2002 to February 2003}

In the present section, we provide a description of the waveform, energy, frequency content and occurrence of explosions, LP events, VT events and volcanic tremor. We also look for correlations between these characteristics and variations of these features that could be related with forthcoming eruptions

\section{Explosions}

Eighteen explosive events occurred from December 2002 to February 2003. All the explosions were related to an open system that allowed continuous magma ascent and a dome formation. This dome extruded in September 2002 and reached a height of $40 \mathrm{~m}$. The first explosion was registered on December 18, 2003 at 08:09 (hereafter we use GMT time) and generated a 6-km-high ash column. This event was followed by another explosion on December 23 at 07:10. According to CENAPRED, the total volume ejected from both explosions was estimated in $500,000 \mathrm{~m}^{3}$. In January 2003, dome growth was reported by CENAPRED (CENAPRED, Volcano Monitoring Reports). Explosive activity resumed in February 2003 with a more intense eruptive phase comprising a series of 16 explosions that partially destroyed the lava dome. Table 1 summarizes the main features of the explosions. E/e refers to a classification by CENAPRED in large explosion (E) and strong degassing event (e). VLP indicates the existence of signal in the period range from 5 to $30 \mathrm{~s}$. A proxy of the energy $\left(E_{k}\right)$ released is calculated as

$$
E=\int_{D} v^{2}(t) d t
$$

where $v(t)$ is the vertical ground velocity recorded at station PPP and it is related to the wave amplitude and the energy released. $D$ is the duration of the corresponding seismic event. The impulse magnitude $M_{k}$ was calculated using the equation determined for Popocatépetl volcano by Cruz-Atienza et al (2001). In most cases, the explosions classified as $\mathrm{E}$ are the most energetic and produced VLP signals. Conversely, many low energy explosions produced long duration signals.

\section{VT events}

All the 50 VT earthquakes that occurred during this period had magnitudes of $\mathrm{m}_{\mathrm{c}}=1.9$ to 2.9 (Martinez-Bringas, 2006) and depths +2 to $-2 \mathrm{~km}$ below sea level (González, 2003). Thirty of these earthquakes were located below the summit crater, while the other 20 were located southeast of the volcanic edifice. This hypocenter distribution is similar to that usually observed on this volcano (Arámbula-Mendoza et al., 2010). The seismic rate for VT events typically averaged one event per day. Besides, a maximum of 3 VTs was observed on January 2. No increase of this kind of seismicity is detected before the explosions. This is consistent with the persistent low level of VT activity at Popocatépetl since its reactivation. The local stress pattern for these events indicate reverse focal mechanism 
solutions for 14 VTs that occurred in November 2002, within a depth range of -1 to $1 \mathrm{~km}$ asl (González, 2003). In December, VT events occurred at greater depths (-2 to $1.5 \mathrm{~km}$ asl). Events were located at depths ranging from 0.5 to $1 \mathrm{~km}$ from late January to April 2003. A predominance of normal fault solutions was observed in February and March (ArámbulaMendoza, 2007; Arámbula Mendoza et al., 2010).

\section{LP events}

LP activity averaged 20 events per day with a maximum of 101 events on February 7, 2003. In order to produce an overview of their features and temporal evolution, about $10 \mathrm{LP}$ events per day of various amplitudes and waveforms were analyzed, giving a total of 908 LPs from November 2002 to February 2003. Several types of LP signatures were identified at Popocatépetl, most of which were characterized by dominant frequencies in the $1-6 \mathrm{~Hz}$ range (Fig. 3). About two thirds of these events exhibited a high-frequency (HF) signal (4$8 \mathrm{~Hz}$ ) occurring generally between 2 to $4 \mathrm{~s}$ before the main LP phase (Fig. 4). These HF precursory signals were characterized by an emergent onset and almost constant amplitude which was about $1 / 20^{\text {th }}$ of that of the LP event. The HF signal was never observed without the LP event, although some LPs were not associated with any HF signal (Fig. 3b). Figure 4 displays the delay between HF and low-frequency (LF) phase arrivals from November 2002 to February 2003. The average duration is $4.4 \mathrm{~s}$ in this period (Fig. 4), with a standard deviation of $1.3 \mathrm{~s}$. Although fluctuations of delay are observed, it is difficult to clearly relate them to the eruptive activity. The amplitude and duration of the LP events in this study are small compared with those of LP events during other periods of activity. For example: in 2000, many events displayed duration of one minute or more (ArciniegaCeballos et al. 2008)

Spectral analysis performed on the 908 LPs showed, for most of them, a dominant peak around 1.8-2.2 Hz (Fig. 5). This feature has been observed at Popocatépetl volcano since 1994, suggesting that the physical conditions at the sources of LP events are stable. No clear variations in the peak frequency can be observed either at long term or at short term in relation with the occurrence of the explosions (Fig. 7d).

\section{Volcanic Tremor}

Two main types of tremor lasting from few minutes up to several hours were observed at Popocatépetl Volcano: harmonic and spasmodic tremor (Fig. 6). Harmonic tremor was the most common type observed during this period. It was characterized by a series of up to 20 narrow spectral peaks, with fundamental frequency usually in the range 0.6 to $1.5 \mathrm{~Hz}$, and regularly spaced overtones at integer multiples of the lowest frequency. Spasmodic tremor had broad spectra with energy at frequencies of up to $12 \mathrm{~Hz}$, maximum values around $2 \mathrm{~Hz}$ and no marked spectral peaks. Some tremor episodes exhibited rapid transitions from harmonic tremor to spasmodic tremor and back to harmonic tremor again. Pulsating tremor, which consists of successive small amplitude pulses every $10 \mathrm{~s}$ approximately, was detected, briefly, in November (Fig. 6c).

Harmonic tremor frequency was not stable through time and presented both short-term glidings (Fig. 6a) and long-term variations. Again, no clear relationship between fundamental frequency of harmonic tremor and surface activity of the volcano could be observed (Fig. 7e). The tremor activity in 2002 peaked in August and September, with 
durations of up to 1200 mins per day, and then decreased. Tremor activity reached 360 mins per day in November and early December. It became more sporadic from December 13 to January 20 and slightly renewed afterwards with durations of up to 180 mins per day.

\section{Correlation between types of events}

We looked for relationships and correlations between the different types of seismic activity comparing the occurrences, features, and inter-event times of the VT, LP events, tremor and explosions. All appeared to be highly uncorrelated to each other (Fig. 7). Thus, no type of event can be considered as a precursor of any other type including explosions. Moreover, the different kinds of seismic activity have probable different origins.

\subsection{RSAM and source location}

In order to have an overview of the level of seismic activity during the period of study, we first calculated the Real-time Seismic Amplitude Measurement (RSAM, Endo and Murray, 1991) from October to February. For all the RSAM calculations, we used the vertical component of the short-period seismometer of PPP, which was the closest station to the crater, with a moving computing window of $60 \mathrm{~s}$ long without overlap. Figure 8 displays the results together with the cumulative values of energy. It appears that the slope of the cumulative curve is almost constant during the last 4 months of the period with an average rate of energy of 730 Arbitrary Unit per hour (AU/h). This mean value includes the short bursts of energy (some of which are associated with explosions) and elevates the mean value. However, most of the time, such as in October, the rate was lower. Apart from some small fluctuations, the seismic energy released was quite stable during the pre-eruptive and eruptive sequences when examined at this scale.

To investigate the explosions more closely, we focused on shorter intervals preceding the explosions, described the behavior of RSAM, and made use of the seismic arrays to locate the origin of eventual seismic activity. The details of five such events vary widely, with some explosions clearly preceded by marked increases in the RSAM for tens of minutes to tens of hours and others apparently preceded by slight RSAM increases several days before with only one case where coherent energy was clearly coming from the volcano. In summary, an acceleration of RSAM could be detected before the eruptions. However, for most of them, no variation could be observed.

\subsubsection{December 18, 2002 eruption.}

Twenty minutes before the eruption, the RSAM sharply increased (Fig. 9a). This activity corresponded to the occurrence of relatively high-frequency $(1-10 \mathrm{~Hz})$ emergent signals, which was probably spasmodic tremor and rock falls. In that period, only array FPX was recording. No preferential back-azimuth was obtained during this 20 minute-long interval, although seismic waves of a small event at 07:48:49 appeared to propagate from the crater.

\subsubsection{December 23, 2002 eruption.}

About 6 hours before the explosion, the RSAM increased from 356 to $1145 \mathrm{AU} / \mathrm{h}$, and again 40 minutes before the event (Fig. 9b). This was mainly due to an increasing level of spasmodic tremor with energy distributed up to $12 \mathrm{~Hz}$ (Fig. 10). The back-azimuths 
estimated at arrays FPX and FCO were random, except at FCO during 40 minutes preceding the explosion, where they pointed towards the volcano.

\subsubsection{February 14, 2003 eruption.}

A small increment of the rate of energy $(870 \mathrm{AU} / \mathrm{h})$ was observed 80 minutes previous to the eruption in association with a swarm of LP $(1-10 \mathrm{~Hz})$ events (Fig. 9c). While backazimuths estimated at array FPP mainly indicated the direction of the crater during several hours before the event, the values obtained at FCO and FPX corresponded to the summit direction only for short periods of tremor or discrete events.

\subsubsection{February 21, 2003 eruption.}

Similarly, the seismicity level progressively rose within the 7-hour interval prior to this small explosion (Fig. 9d). Again, the signals contained low amplitude spasmodic tremor, mainly recorded at the closest stations, with some bursts of energy or LP events, all in the frequency range $1-12 \mathrm{~Hz}$. Strangely, array processing at FPP gave a greater proportion of back-azimuths pointing towards the crater before this period of increasing signal level than during it. This indicates that the signals during this pre-eruptive period contained higher proportion of incoherent noise.

\subsubsection{February 28, 2003 explosion.}

Finally, this event was preceded by a slight increment of the seismic energy rate ( 810 AU/h) during about 50 hours (Fig. 9c,e). The period began with a swarm of LP events and spasmodic tremor on February 12 between 10:00 and 23:00 (Fig. 9c). The back-azimuths estimated at FPP were relatively stable and pointed to the crater, especially in the last 12 hours (Fig. 11b). Similar results, with a lower proportion of good quality estimations, were obtained for the other arrays. Furthermore, as observations from 3 arrays were available for this period, many LP events, including the explosion itself, could be located by combining the estimations of back-azimuths (Métaxian et al., 2002). The source locations obtained were close to each other and were at less than $1 \mathrm{~km}$ south-westward of the crater (Fig. 12). This shift could result from topographical and structural effects (Almendros et al., 2001; Métaxian et al., 2009).

\subsubsection{Other eruptions.}

On the other hand, no increase of energy release was observed before the explosions of February 3, 5, 6, 7, 19, 20, 22, 23, and 28 (Fig. 9e). A small decrease even occurred 2 hours before the February 3 eruption.

\section{DISCUSSION}

As at most active volcanoes, the seismic activity of Popocatépetl is characterized by a wide variety of phenomena. A crucial question is to determine the relationships between the seismicity and the physical processes associated with dome extrusion and its subsequent destruction. This is especially the case for the period from October 2002 to February 2003 which the present study is focused on. 
The volcano-tectonic activity is of low level at Popocatépetl compared with other similar volcanoes. It is mainly located in two areas, one below the crater and the other at the southeast of the edifice. Most of the fault plane solutions indicate normal faulting although the number of reverse fault mechanisms increases in some periods (Arámbula-Mendoza et al., 2010). During the period of study, this type of event was even scarcer with less than one event per day in average. However, no clear variations of the pattern of this seismicity, including hypocenter distributions and fault plane mechanisms, could be observed. Furthermore, no anomalous behavior of the VT activity occurred before the explosions. These observations suggest that the solid structure of the volcano did not experience marked stress variations in relation with the explosive events and dome extrusions. These results are consistent with the deformation data from 2002 and early 2003 provided by CENAPRED. Deformation of the volcanic edifice showed no significant changes from October 2002 to February 2003, a behavior indicative of an open-conduit system.

Long-period events are the most common signals recorded at Popocatépetl during the period of time studied here. Their spectra exhibit one or several peaks with varying frequencies although they are generally close to $2 \mathrm{~Hz}$. Part of them, especially before explosions, have energy up to $12 \mathrm{~Hz}$. Only a small proportion of LP events are characterized by strong spectral peaks that could be associated to resonance effects at the source. The diversity of features of the LP seismicity suggests that sources of different kinds and/or locations are active in this volcano. Neither the number of events per day nor their characteristic frequency present anomalous variations related with the explosions. Only mild increases of this seismicity have been observed during a few minutes or hours prior some events. Arciniega-Ceballos et al. (2008) described the seismicity of Popocatepetl from December 1999 to March 2000. They identify three types of LP events, two of which are associated with VLP events and strong degassing bursts. These authors interpret the former events as the expulsion of pockets of gas through pre-existing cracks. Although the LP events observed three years later are much smaller, the same mechanism related to gas transfer could also be involved at the source.

Most of LP events are preceded by a relatively high-frequency and low-amplitude phase. This striking feature has been observed since the unrest of Popocatépetl in 1994 (ArciniegaCeballos et al., 2008). This kind of signal is also common at Galeras, Colombia (Gil Cruz and Chouet 1997), Koryakski, Russia (Gordeev and Senyukov 2003), Deception Island (Ibañez et al., 2003), and Shishaldin volcano, Alaska (Caplan-Auerbach and Petersen 2005). Several processes have been proposed to explain these HF phases and could provide an explanation for the observation at Popocatepetl. Gil Cruz and Chouet (1997) suggested that at Galeras they are originated by a conduit segment that connects a system of preexisting cracks, where LPs are generated, to the underlying magma reservoir. The conduit segment is excited by the frothy liquid that results from a foam layer located at the top of the magma column and that collapses episodically when pressurized gas escapes to the surface. Ibañez et al. (2003) propose different locations for the LP and HF sources, the latter resulting from the fracturing of small fluid-lubricated faults. In a study of Shishaldin volcano, Caplan-Auerbach and Petersen (2005) described a model in which the HF signals result from pressure perturbations in a fluid flow which generate transient waves. These waves propagate in the fluid until producing bubble coalescence and LP event. At 
Shishaldin volcano, they observed periods of relatively stable delays between the HF and LF phases. Changes in those delays are related to variations of the acoustic velocity in the fluid due to changes in gas content. From November 2002 to February 2003 at Popocatépetl volcano, the average HF-LF delay remained around $4 \mathrm{~s}$ and no clear variations of this duration appeared before the explosions (Fig. 4). Further detailed studies and observations are required to evaluate the ability of the former models to explain this HF precursory signal.

The occurrence of volcanic tremor remained sporadic during the five-month-long period of study and no correlation has been found between the eruptive events and the duration or frequency of tremor. Tremor is thought to be mainly related to degassing (Konstantinou and Schlindwein, 2002). Among the numerous mechanisms proposed to explain this phenomenon (see e.g. Ferrazzini and Aki, 1987; Chouet, 1988; Johnson and Lees, 2000; Julian, 1994; 2000; Schlindwein et al., 1995; Hellweg, 2000; Powell and Neuberg, 2003), the clarinet model (Lesage et al., 2006) appears to be one of the most plausible to produce the observed signals (Rust et al., 2008). Following this model, intermittent gas flow through fractures in the plug produces repetitive pressure pulses that can be stabilized, or not, by a feedback mechanism associated with resonance in the magmatic conduit. This mechanism could explain the evenly spaced spectral peaks of the tremor of Popocatépetl volcano.

The calculation of RSAM showed that the rate of seismic energy release is remarkably stable over the 5 months. Except for a few cases, the rate varied by less than a factor of 2 . This suggests that the volcanic system did not suffer large modifications during the eruptive sequence. At a shorter time scale, no variation of the RSAM rate was observed prior to most of the 18 explosions. Only for five of them, among the largest ones, low level and short-lived (tens of minutes to tens of hours) precursory seismic activity occurred and generated an increase in the RSAM values. This activity generally consisted of relatively high-frequency $(<12 \mathrm{~Hz})$ spasmodic tremor, LP events and background noise. The processing of array data, for such events, confirms that the corresponding sources are close to the crater, probably at shallow depth.

The most important point with respect to the pre-eruptive activity is that acceleration of the energy release did not generally occur before the explosions, even for the largest ones. This behavior is in clear contrast with that of the seismic activity reported on many volcanoes, such as Pinatubo (Cornelius and Voight, 1996), Bezymyanny (Voight, 1988), Mt. St. Helens and Redoubt (Voight and Cornelius, 1991), Villarrica (Ortiz et al., 2003), Soufrière Hills (Kilburn and Voight, 1998), or Tungurahua (Tárraga et al., 2007). In many cases, the eruption time could be successfully estimated by using the Material Failure Forecast Method (FFM) which is based on the concept of material damaging before a rupture (Voight, 1988; Cornelius and Voight, 1994). In these examples, the acceleration of the observable, such as deformation or seismic activity level, is proportional to a power of its rate of change. A variant of the FFM model, which uses a linear visco-elastic model of Kelvin-Voigt, has been applied to eruptions of the Colima volcano (De la Cruz-Reyna and Reyes-Dávila, 2001; Reyes-Dávila and De la Cruz-Reyna, 2002). Following this interpretation, tertiary creep of material, involving progressive loss of cohesion, is identified by the accompanying phenomena that can be used as precursors of the eruption. 
However, this process requires the medium to be closed, as an open or semi-open system may have different behavior (De la Cruz-Reyna and Reyes-Dávila, 2001). This approach can thus provide a possible explanation of either the lack or weakness of seismic precursors before the Popocatépetl explosions. Indeed, as dome emplacement occurred a few days or weeks before the eruptions, the magma system was probably still open.

From another point of view, complex processes strongly modify the physical properties of the magma in the uppermost part of the feeding conduit, including the dome if any. Degassing and microlites growth produce dramatic viscosity increase and large excess fluid pressures at the top of the conduit and in the dome. This pressurization may lead to instabilities and unexpected explosions (Sparks, 1997). These phenomena are not necessarily accompanied by seismic activity and could thus give another interpretation of our observations.

All the preceding analysis and discussion, together with the fact that some seismic bursts were not followed by explosions, demonstrate that it would have been very difficult, if not impossible, to predict the eruptions of December 2002 and February 2003. However, in such situations, the high level of hazard of the volcano could be identified, with the corresponding implications in terms of civil protection. The results we have presented in this paper highlight the variability of precursory signals or lack thereof in a volcano with an open-conduit system. It also stresses the importance of the use and interpretation of different monitoring techniques to determine the current state of the volcano. Yet, further analysis of future eruptive stages without precursory signals is required for a better understanding of volcanic activity at Popocatépetl.

\section{CONCLUSIONS}

Many papers in the volcanological literature present observations of more or less clear precursors of eruptions and attempts to predict these events, mostly, in an a posteriori approach. There are much fewer papers that analyze the lack or faintness of precursory phenomena that characterize some eruptions, although these observations are quite important for risk assessment. Hence several relevant questions must be addressed such as: in which cases a forthcoming eruption is preceded by precursors? How is the existence or lack of precursors related to the state of the system, the physical properties of the magma and the recent surface activity? To answer these questions a better understanding of the physical processes that lead to eruptions is required.

The present work is focused on a short period of dome building and explosive destruction at Popocatépetl volcano. Many features of the seismic activity have been studied in detail in order to detect possible precursory phenomena: rate of occurrence of VT, LP and tremor, characteristic frequency, fault mechanism and source location, and duration of the precursory HF phase of LP events. The main result of this study is that the December 2002 and February 2003 explosions are characterized by a lack or a weakness of the seismic precursors. Only in a few cases, moderate increase of the level of seismicity has been observed in short period (minutes to hours) before the explosion. Conversely some bursts of seismic activity were not followed by an eruption. In this situation, it is thus difficult to 
identify reliable precursors. This is a consequence of the open state of the system, although precursory activity can be observed in some open systems. It is therefore of paramount importance to detect this kind of situation and to take it into account for risk assessment and protection of the population and, in particular, of the volcanologists that work on the volcano.

\section{ACKNOWLEDGEMENTS}

We would like to thank Enrique Guevara and Gilberto Castelán Pescina of the Centro Nacional de Prevención de Desastres (CENAPRED) for the data from the permanent network provided for this study. German Espitia-Sánchez (CENAPRED), Marcos GaliciaLópez and Francisco Galicia of Protección Civil del Estado de México, Sargento Fidel Limón of the VI Región Militar, Sebastián Araujo, Jean-Philippe Métaxian and Raúl Arámbula-Mendoza for their participation in the field experiment and logistics. Funding for the experiment was provided by the Centre de Recherches Volcanologiques, Program PNRN, INSU, University of Savoie, Ariel Program and program ECOS/ANUIES/CONACyT/SEP. We are grateful to Steve Simpson, Saska Gjorgjievska for very helpful comments on the first draft. We would also like to thank the two anonymous reviewers for their helpful comments to improve this work. Part of the present work was carried out during a secondment of one of us (P.L.) to the Instituto de Geofísica at UNAM, which was funded by the Institut de Recherche pour le Devéloppement.

\section{REFERENCES}

Almendros, J., Chouet, B. and Dawson, P., 2001. Spatial extent of a hydrothermal system at Kilauea volcano, Hawaii, determined from array analyses of shallow long-period seismicity, part II: Results. Journal of Geophysical Research, 106(B7): 1358113597.

Almendros, J., Chouet, B. and Dawson, P., 2002. Array detection of a moving source. Seismological Research Letters, 73(2): 153-165.

Arámbula-Mendoza, R. 2002. Interpretación del tremor armónico registrado en el volcán Popocatépetl durante la crisis eruptiva de diciembre de 2000. [B. Thesis], Universidad Nacional Autónoma de México.

Arámbula-Mendoza, R., 2007. Estado de esfuerzos en el volcán Popocatépetl obtenido con mecanismos focales en el periodo de actividad de 1996 a 2003 [M.S. Thesis], México, D.F.: Universidad Nacional Autónoma de México, 120 pp.

Arámbula-Mendoza, R., 2010, Valdés-González, C., Martínez-Bringas, A., 2010. Temporal and spatial variation of the stress state of Popocatépetl Volcano, México. v. 196, no. 3-4. p. 156-168.

Arciniega-Ceballos, A., Chouet, B., and Dawson, P., 2003. Long-period events and tremor at Popocatepetl volcano (1994-2000) and their broadband characteristics. Bulletin of Volcanology, v. 65, no. 2, p. 124-135.

Arciniega-Ceballos, A., Chouet, B., Dawson, P., and Asch, G., 2008. Broadband seismic measurements of degassing activity associated with lava effusion at Popocatépetl 
Volcano, Mexico. Journal of Volcanology and Geothermal Research, v.170, no. 1-2, p. 12-23.

Brantley, S.R., editor, 1990. The eruption of Redoubt Volcano, Alaska, December 14, 1989 - August 31, 1990. U.S. Geological Survey Circular C 1061, 33 p., available at http://www.dggs.dnr.state.ak.us/webpubs/usgs/c/text/c-1061.PDF

Camacho, H. 1925. Resultados de la visita al cráter del Popocatépetl el 9 de marzo de 1922. Anales del Instituto Geológico de México, v. 2, p. 64-66.

Caplan-Auerbach, J., and Petersen, T., 2005. Repeating coupled earthquakes at Shishaldin Volcano, Alaska. Journal of Volcanology and Geothermal Research, v.145, no. 1-2, p. 151-172.

CENAPRED, Centro Nacional de Prevención de Desastres. Volcano Monitoring Reports, available at http://www.cenapred.unam.mx/cgi-bin/popo/reportes/consulta.cgi. Last access to the site: December 29, 2011

Chouet, B., 1988. Resonance of a fluid-driven crack: radiation properties and implications for the source of long-period events and harmonic tremor. Journal of Geophysical Research, v. 93, B5, p. 4375-4400.

Chouet, B., Dawson, P., and Arciniega-Ceballos, A., 2005. Source mechanism of Vulcanian degassing at Popocatépetl Volcano, Mexico, determined from waveform inversions of very long period signals. Journal of Geophysical Research, v.110, B7, B07301.

Cornelius, R. R., Voight, B., 1994. Seismological aspects of the 1989-1990 eruption at Redoubt Volcano, Alaska: The Materials Failure Forecast Method (FFM) with RSAM and SSAM seismic data. Journal of Volcanology and Geothermal Research 62, 469-498.

Cornelius, R. R., Voight, B. 1996. Real-time Seismic Amplitude Measurement (RSAM) and Seismic Spectral Amplitude Measurement (SSAM) analyses with the Materials Failure Forecast Method (FFM), June 1991 explosive eruption at Mount Pinatubo. In: C.G. Newhall, R.S. Punongbayan (Eds.), Fire and Mud: Eruptions and Lahars of Mount Pinatubo, Phillipines, University of Washington Press, Seattle, WA, pp. 249268.

Cruz-Atienza, V., Pacheco, J.F., Singh, SK., Shapiro, NM., Valdés C., and Iglesias, A., 2001: Size of Popocatépetl volcano explosions (1997 - 2001) from waveform inversions of very long period signals. Journal of Geophysical Research, v.110, B7, B07301.

De la Cruz-Reyna, S., and Reyes-Dávila, G., 2001. A model to describe precursory material-failure phenomena: applications to short-term forecasting at Colima volcano, Mexico. Bulletin of Volcanology, v.63, no. 5, p. 3-22.

De la Cruz-Reyna, S., Quezada, J.L., Peña, C., Zepeda, O. and Sánchez, T., 1995, Historia de la actividad reciente del Popocatépetl: Volcán Popocatépetl: Estudios realizados durante la crisis de 1994 - 1995, p. 195 - 230. CENAPRED-UNAM, Mexico.

De la Cruz-Reyna, S., Yokoyama, I., Martínez-Bringas, A., and Ramos, E.. 2008. Precursory seismicity of the 1994 eruption of Popocatépetl Volcano, Central Mexico. Bulletin of Volcanology. v.70, no. 6, p.753-767.

De la Rosa, F., C. Valdés-González, and C.A. Gutiérrez-Martínez. 2003. Análisis de patrones sísmicos asociados a algunas explosiones $\mathrm{y}$ emisiones de ceniza 
importantes del volcán Popocatépetl. Revista Geofísica. Instituto Panamericano de Geografía e Historia, v.58, p. 97-134.

Endo, E. \& Murray, T., 1991. Real-Time Seismic Amplitude Measurement (RSAM): a volcano monitoring and prediction tool. Bulletin of Volcanology, 53:533 - 545.

Ferrazzini, V. and Aki, K., 1987. Slow waves trapped in a fluid-filled infinite crack: implication for volcanic tremor. Journal of Geophysical Research, v. 92, p. 92159223.

Fréchet, J., Sismogénèse et doublets sismiques [Ph.D. thesis], Université Scientifique et Medicale de Grenoble, 1985.

Gil Cruz, F., and Chouet, B.A., 1997. Long-Period events, the most characteristic seismicity accompanying the emplacement and extrusion of a lava dome in Galeras Volcano, Colombia, 1991. Journal of Volcanology and Geothermal Research, v.77, no.1-4, p. $121-158$.

Global Volcanism Network Bulletin, 2002a. Smithsonian Institute Bulletin, Washington, D.C. $27,02$.

Global Volcanism Network Bulletin, 2002b, Smithsonian Institute Bulletin, Washington, D.C. $27,06$.

Global Volcanism Network Bulletin, 2003a, Smithsonian Institute Bulletin, Washington, D.C. $28,08$.

Global Volcanism Network Bulletin, 2003b, Smithsonian Institute Bulletin, Washington, D.C. $28,02$.

Global Volcanism Network Bulletin, 2005, Smithsonian Institute Bulletin, Washington, D.C. 30,01 .

Global Volcanism Network Bulletin, 2006, Smithsonian Institute Bulletin, Washington, D.C. 31, 05.

González Pomposo, Guillermo J., 2003. Análisis de la sismicidad asociada a la actividad del volcán Popocatépetl y determinación de su estructura por medio de tomografía sísmica [PhD Thesis]. Mexico, D.F., Universidad Nacional Autónoma de México.

Gordeev, E. I., and Senyukov, S.L., 2003. Seismic activity at Koryakski volcano in 1994: hybrid seismic events and their implications for forecasting volcanic activity. Journal of Volcanology and Geothermal Research, v.128, no.1-3, p.225-232.

Got, J.-L., Fréchet, J., and F.W. Klein, 1994. Deep fault plane geometry inferred from multiplet relative relocation beneath the south flank of Kilauea, Journal of Geophysical Research, v. 99, p. 15,375-15,386.

Hellweg, M. 2000. Physical models for the source of Lascar's harmonic tremor. Journal of Volcanology and Geothermal Research, v.101, no.1-2, p.183-198.

Johnson, J.B. and Lees, J.M., 2000. Plugs and chugs - seismic and acoustic observations of degassing explosions at Karymsky, Russia and Sangay, Ecuador. Journal of Volcanology and Geothermal Research, v. 101, p. 67-82.

Julian, B.R., 1994. Volcanic tremor: Nonlinear excitation by fluid flow. Journal of Geophysical Research, v. 99, p. 11859-11877.

Kilburn, C. R. J., Voight, B., 1998. Slow rock fracture as eruption precursor at Soufriere Hills Volcano, Montserrat, Geophysical Research Letters, 25, 3665-3668. 
629

630

631

632

633

634

635

636

637

638

639

640

641

642

643

644

645

646

647

648

649

650

651

652

653

654

655

656

657

658

659

660

661

662

663

664

665

666

667

668

669

670

671

672

Konstantinou, K.I., Schlindwein, V., 2003. Nature, wavefield properties and source mechanism of volcanic tremor: a review. Journal of Volcanology and Geothermal Research, v.119, no.1-4, p. 161-187.

Lermo, J., J. Cuenca, F.J. Chavez-Garcia, A. Huidobro, M.L. Bermudez, M. Rodriguez, R. Quaas, et al. 1996. Características espectrales de temblores tipo-A, tipo-B y tremores asociados a la erupción del volcán Popocatépetl, México, en diciembre de 1994: Volcán Popocatépetl: Estudios realizados durante la crisis de 1994 - 1995, p. 139 - 166. México, D.F, CENAPRED-UNAM.

Lermo-Samaniego, J., Antayhua-Vera, Y., and Chavacán-Avila, M.. 2006. Análisis de la actividad sísmica en el Volcán Popocatépetl (México) durante el período 1994 1997: Número Especial de Geología Urbana LVIII, no. 2, p. 253 - 257.

Lesage, Ph., and Surono. 1995. Seismic precursors of the February 10, 1990 eruption of Kelut volcano, Java. Journal of Volcanology and Geothermal Research, v.65, no.12, p. 135 - 146.

Lesage, P., Mora, M., Alvarado, G., Pacheco, J.F. and Métaxian, J.-P., 2006. Complex behavior and source model of the volcanic tremor at Arenal volcano, Costa Rica. J. Volcanol. Geotherm. Res., v. 157, p. 49-59.

Macías, J. L., and Siebe, C., 2005. Popocatépetl's crater filled to the brim: significance for hazard evaluation. Journal of Volcanology and Geothermal Research, v.141, no. 34, p. 327-330.

Martin-Del Pozzo, A. L., Cifuentes, G., Cabral-Cano, E., Bonifaz, R., Correa, F. and Mendiola, I. F. 2003. Timing magma ascent at Popocatepetl Volcano, Mexico, 2000-2001. Journal of Volcanology and Geothermal Research, v.125, no.1-2, p.107120.

Martinez-Bringas, A. 2006. Variaciones temporales de la atenuación de las ondas coda y del valor de b, asociadas a la actividad del volcán Popocatépetl de 1995 a 2003 [Ph.D Thesis], Mexico, D.F., Universidad Nacional Autónoma de México.

Métaxian, J.-P., P. Lesage, and B. Valette, 2002. Locating sources of volcanic tremor and emergent events by seismic triangulation: Application to Arenal volcano, Costa Rica, Journal of Geophysical Research, v. 107, 2243.

Métaxian, J.-P., O'Brien, G.S., Bean, C.J. and Mora, M., 2009. Locating volcano-seismic signals in the presence of rough topography: Wave simulations on Arenal volcano, Costa Rica. Geophysical Journal International.

Murillo, G. 1939. Volcanes de México. London: Polis.

Novelo-Casanova, D.A. and Valdés-González, C., 2008. Seismic pattern recognition techniques to predict large eruptions at the Popocatépetl, Mexico, Journal of Volcanology and Geothermal Research, v. 176, no. 4, p. 583-590.

Ortiz, R., H. Moreno, A. García, G. Fuentealba, M. Astiz, P. Peña, N. Sánchez, M. Tárraga, 2003. Villarrica volcano (Chile): characteristics of the volcanic tremor and forecasting of small explosions by means of a material failure method. Journal of Volcanolology and Geothermal Research, v.128, p. 247-259.

Poupinet, G., W.L. Ellsworth, and J. Frechet. 1984. Monitoring velocity variations in the crust using earthquake doublets: An application to the Calaveras Fault, California, Journal of Geophysical Research, v. 89, p. 5719-5731. 
Powell, T.W. and Neuberg, J., 2003. Time dependent features in tremor spectra. Journal of Volcanology and Geothermal Research, v. 128 p.177-185

Reyes-Dávila, D.A., and De la Cruz-Reyna, S., 2002. Experience in the short term eruption forecasting at Volcán de Colima, México, and public response to forecasts. Journal of Volcanology and Geothermal Research, v. 117, p. $121-127$.

Rust, A.C., Balmforth, N.J. and Mandre, S., 2008. The feasibility of generating lowfrequency volcano seismicity by flow through a deformable channel: S.J. Lane and J.S. Gilbert (Editors), Fluid motions in volcanic conduits: a source of seismic and acoustic signals. Geological Society, Special Publications, London, pp. 45-56.

Schlindwein, V., Wassermann, J. and Scherbaum, F., 1995. Spectral analysis of harmonic tremor signals at Mt. Semeru volcano, Indonesia. Geophysical Research Letters, v. 22, p.1685-1688.

Siebe, C., Abrams, Mm and Macias, J.L., 1995. Derrumbes gigantes, depósitos de avalancha de escombros y edad del actual cono del Volcán Popocatépetl: Volcán Popocatépetl: Estudios realizados durante la crisis de 1994 - 1995, p. 195 - 230. CENAPRED-UNAM, Mexico.

Sparks, R.S.J., 1997. Causes and consequences of pressurization in lava dome eruptions. Earth and Planetary Science Letters, v. 150, p. 177-189.

Swanson, D.A., T.J. Casadevall, D. Dzurisin, R.T. Holcomb, C.G. Newhall, S.D. Malone and C.S. Weaver. 1985. Forecasts and predictions of eruptive activity at Mount St. Helens, USA: 1975-1984. Journal of Geodynamics, v. 3, no. 3-4, p. 397-423.

Tarraga E. M., 2007. Análisis Dinámicos de Series Sismo Volcánicas. Estudio de los Volcanes, Villarrica, Tungurahua, Stromboli y Teide. [PhD Thesis]. Departamento de Física, Astronomía y Astrofísica I, Facultad de Ciencias Físicas, Universidad Complutense de Madrid. pp. 214.

Umakoshi, K., H. Shimizu, and N. Matsuwo. 2001. Volcano-tectonic seismicity at Unzen Volcano, Japan, 1985-1999. Journal of Volcanology and Geothermal Research, v.112, no. 1-4, p. 117-131.

Valdés, C., De la Cruz, S., Martínez, A., Quaas, R. and Guevara, E.. 2002. Resumen de la actividad del Volcán Popocatépetl de diciembre 1994 a mayo 2001: Las cenizas del volcán Popocatépetl y sus efectos para la aeronavegación e infraestructura portuaria, p. 21 - 24. México, D.F. CENAPRED.

Voight, B., 1988. A method for prediction of volcanic eruptions. Nature, 332: 125-130.

Voight, B., Cornelius, R. R., 1991. Prospects for eruption prediction in near real-time. Nature, 350, 695-698.

Voight, B., Young, K.D., Hidayat, D., Subandrio, Purbawinata, M. A., Ratdomopurbo, A., Suharna, Panut, Sayudi, D.S, R. LaHusen, J. Marso, T. L. Murray, M. Dejean, M. Iguchi, and K. Ishihara. 2000. Deformation and seismic precursors to dome-collapse and fountain-collapse nuées ardentes at Merapi Volcano, Java, Indonesia, 1994 1998. Journal of Volcanology and Geothermal Research, v. 100, no. 1-4, p. 261 287.

Waitz, Paul. 1921. Popocatepetl again in activity. American Journal of Science, v. 1, no.1, p. $81-87$.

Wohletz, K. H. 1986. Explosive magma-water interactions: Thermodynamics, explosion mechanisms, and field studies. Bulletin of Volcanology, v. 48, no. 5, p. 245-264. 
742

743

744

745

746

747

748

749

750

751

752

753

754

755

756

757

Wohletz, K., 2002. Water/magma interaction: some theory and experiments on peperite formation. Journal of Volcanology and Geothermal Research, v. 114, no.1-2, p. 1935 .

\section{TABLE AND FIGURE CAPTIONS}

Figure 1. Permanent monitoring seismic network and temporal arrays used in this study at Popocatépetl volcano, Mexico. The black solid triangles indicate the permanent network and the lighter solid triangles the temporary small-aperture arrays. The squares indicate nearby towns.

Figure 2. Seismicity at Popocatépetl volcano from January 2002 to March 2003 reported by CENAPRED: a) Number of LPs recorded daily, b) Number of VTs recorded daily and c) Total tremor duration per day in minutes. Dashed vertical lines indicate the days the explosive events occurred. The shaded area corresponds to the period analyzed in this paper.

Figure 3. LP events observed at Popocatépetl volcano. For each example, seismogram, spectrogram (short-term Fourier Transform) and spectrum of section between vertical dotted lines are displayed. a) Common LP event recorded on February 13, 2003 at 15:51. b) LP event recorded on December 13, 2002 at 04:13. It is preceded by a high-frequency (1-13 $\mathrm{Hz}$ ) precursory signal with duration of $6 \mathrm{~s}$, the spectrum of which is plotted in bottom panel. c) Relatively high-frequency event recorded on February 4, 2003 at 10:12, 47 minutes before explosion.

Figure 4. Delay between the high-frequency (HF) phase and the low-frequency signal of LP events. Dashed lines indicate the days the explosive events occurred. No significant changes were observed prior to the explosions.

Figure 5. Histogram of the frequency of the maximal spectral amplitude of LP events from November 2002 to February 2003. All the events were recorded with a broad-band seismometer at Canario station (PPP). Note that the energy for most LP events is concentrated around $2 \mathrm{~Hz}$.

Figure 6. Examples of different types of volcanic tremor observed at Popocatépetl volcano. a) Spasmodic tremor (from 1000 to $2300 \mathrm{~s}$ ) followed by harmonic tremor, recorded on December 10, 2002 at 10:21. Averaged periodograms of sections of spasmodic (green dotted lines) and harmonic (red dotted lines) tremors are displayed in two bottom panels with logarithmic vertical scale. Spectrum of harmonic tremor contains 12 clear regularly spaced peaks. b) Spasmodic tremor recorded on December 18, 2002, at 07:54 before 
explosion of 08:07. c) Tremor composed of series of short pulses recorded on November 11, 2002. This kind of tremor was observed only sporadically.

Figure 7. Main features of the seismicity observed from November 2002 to February 2003: a) Number of LP events per day; b) Number of VT events per day; c) Tremor duration; d) Frequency of the maximum spectral amplitude of LP events (The black vertical lines indicate the frequency range observed on each LP event), and e) Frequency of the fundamental spectral peak of harmonic tremor.

Figure 8. Real-time Seismic Amplitude Measurement (RSAM) of the vertical short-period component of stations PPP from October 1, 2002 to February 28, 2003. A moving window of $60 \mathrm{~s}$ with no overlap is used for the calculation. The cumulative value of RSAM is also plotted. Vertical dashed lines indicate the occurrence of explosions.

Figure 9. RSAM and cumulative value of RSAM for several periods enclosing the eruptive events of: a) December 18; b) December 23; c) February 21; d) February 14; e) February 28. Vertical dashed lines indicate the occurrence of the explosions. Arrows mark increases in RSAM rate.

Figure 10. Seismic record obtained with the vertical short-period component of station PPP and corresponding spectrogram before the December 23 explosion. The explosion onset is close to second 4000 .

Figure 11. Time series of back-azimuth estimated at: a) array FCO on December 23, 2002; b) array FPP on February 14, 2003. The vertical line indicates the beginning of the explosion. On the right panels, the probability density function of the back-azimuth is represented for the shadowed 40-minutes long window before the December explosion and for the whole 2-hours window in February. Note the rapid azimuth variation around second 2000 at array FCO, probably due a moving vehicle travelling on a road close to the array (Almendros et al., 2002).

Figure 12. Probability density functions of source position computed for the explosion of February 14, 2003 at 11:34:26 and five LP events that occurred during the preceding three days. For each event, calculations are performed on a $10 \mathrm{~s}$ time window of signal recorded by three seismic arrays (FPP, FPX and FCO). The position of the source is given by the maximum of likelihood indicated as a white star. The day and the beginning of time windows are indicated above each panel.

Table 1. Main features of the explosions of Popocatépetl volcano in December 2002 and February 2003. E and e indicate large explosion and strong degassing event, respectively. 'Precursors' and 'VLP' columns indicate events preceded by precursors and containing 
very long period signals. $M_{k}$ is the impulse magnitude (Cruz-Atienza et al., 2001). $E_{k}$ is a

800 proxy of the energy of the explosion quakes. The last column gives their duration (in s.).

801

802

803 Quezada-Reyes_etal_Figure1.cdr

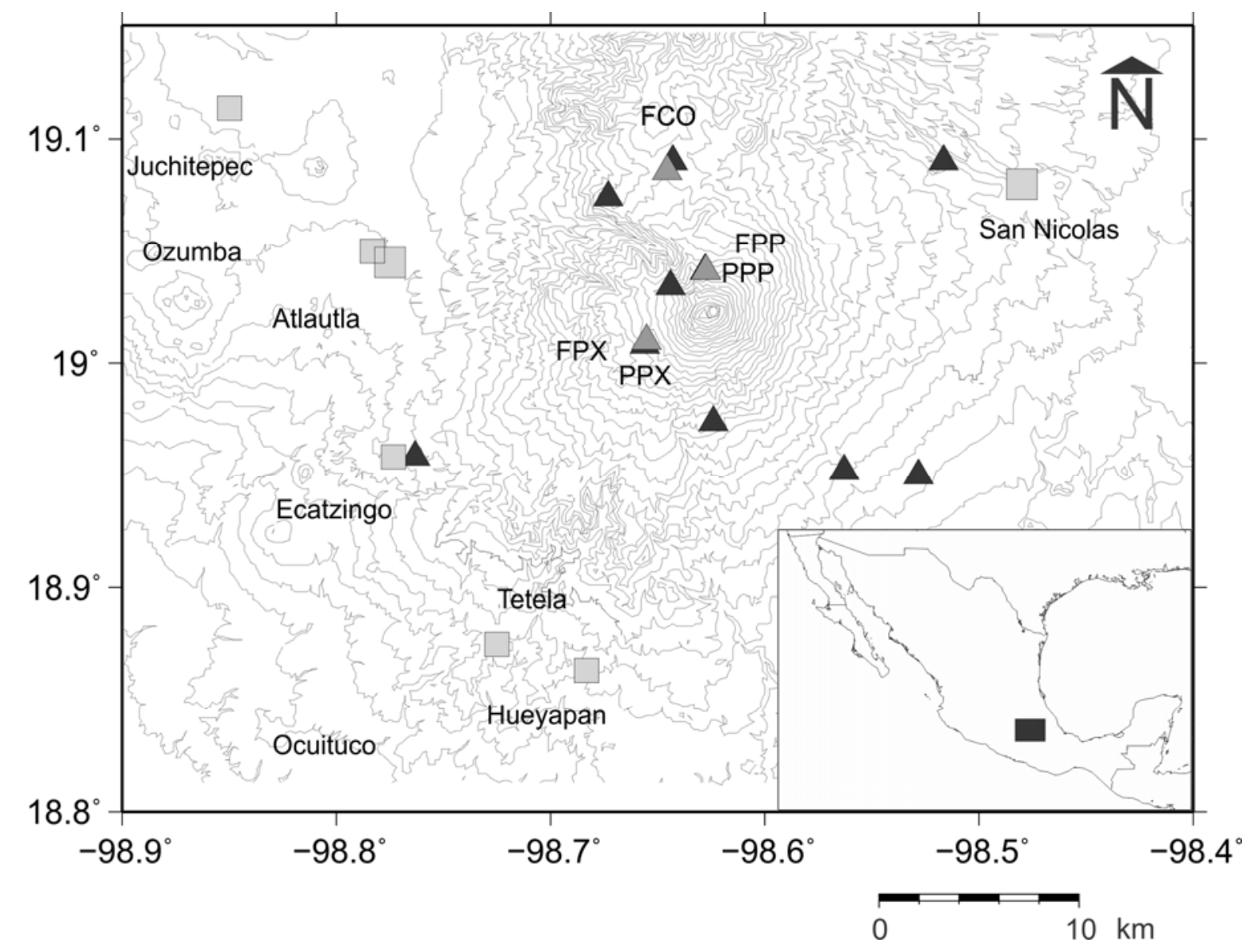

805

806

807 Quezada-Reyes_etal_Figure2.cdr 


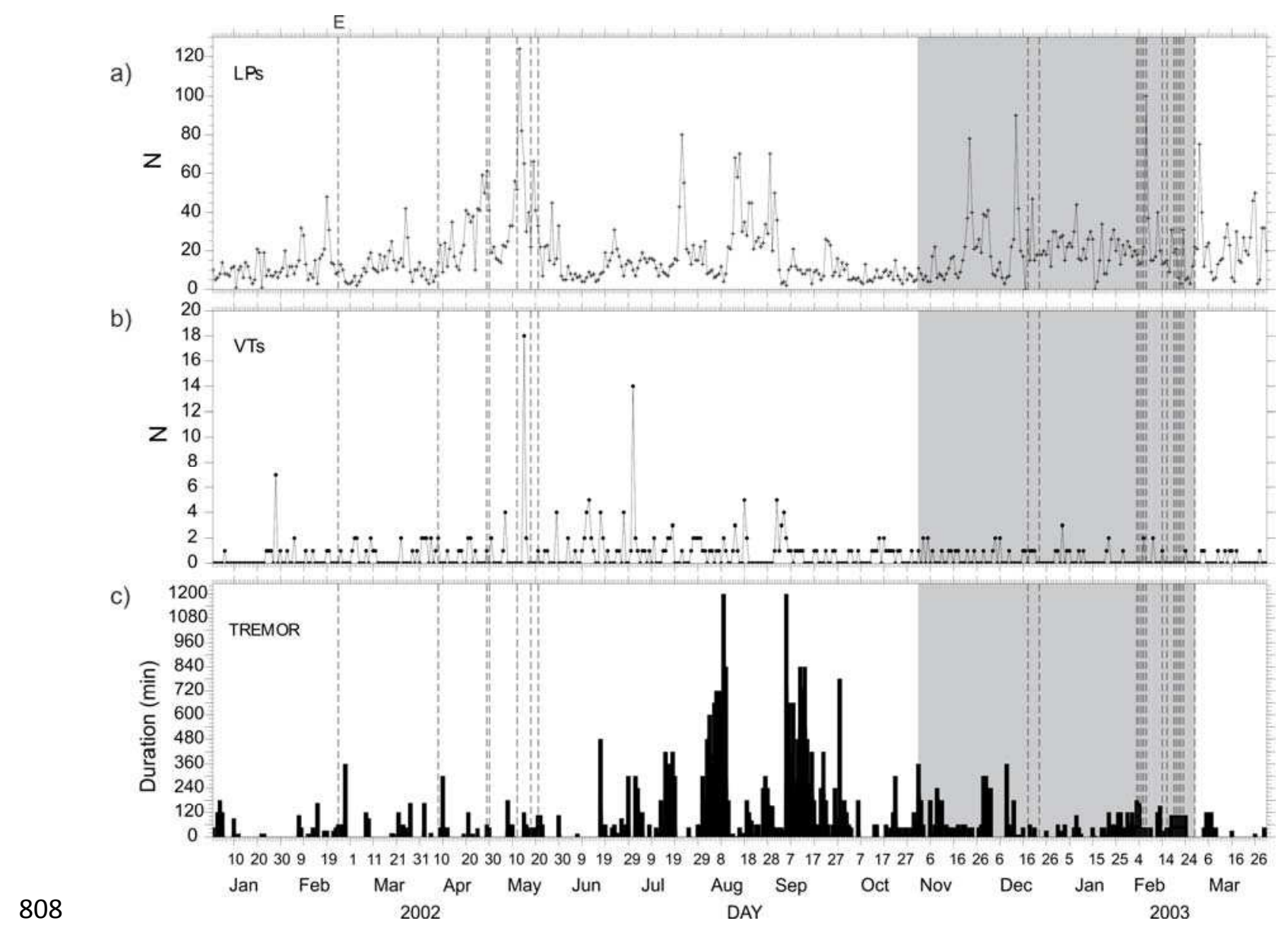

809

Quezada-Reyes_etal_Figure3.cdr

a)
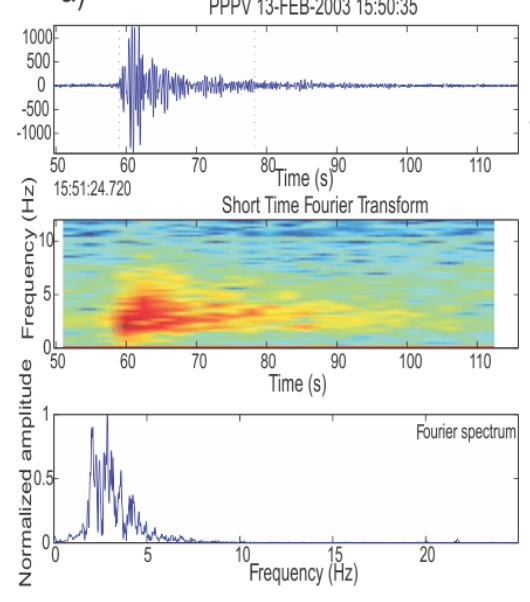

811 b)
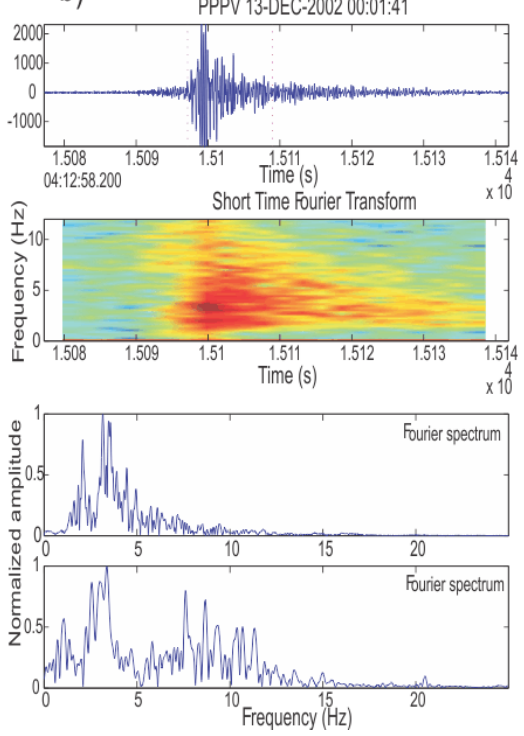
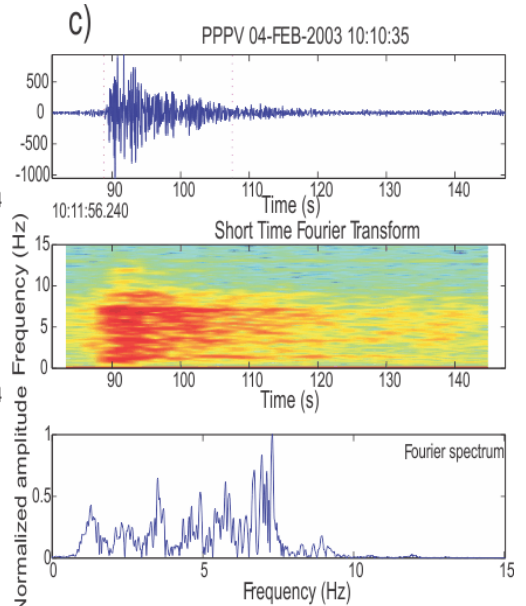
Quezada-Reyes_etal_Figure4.cdr

813

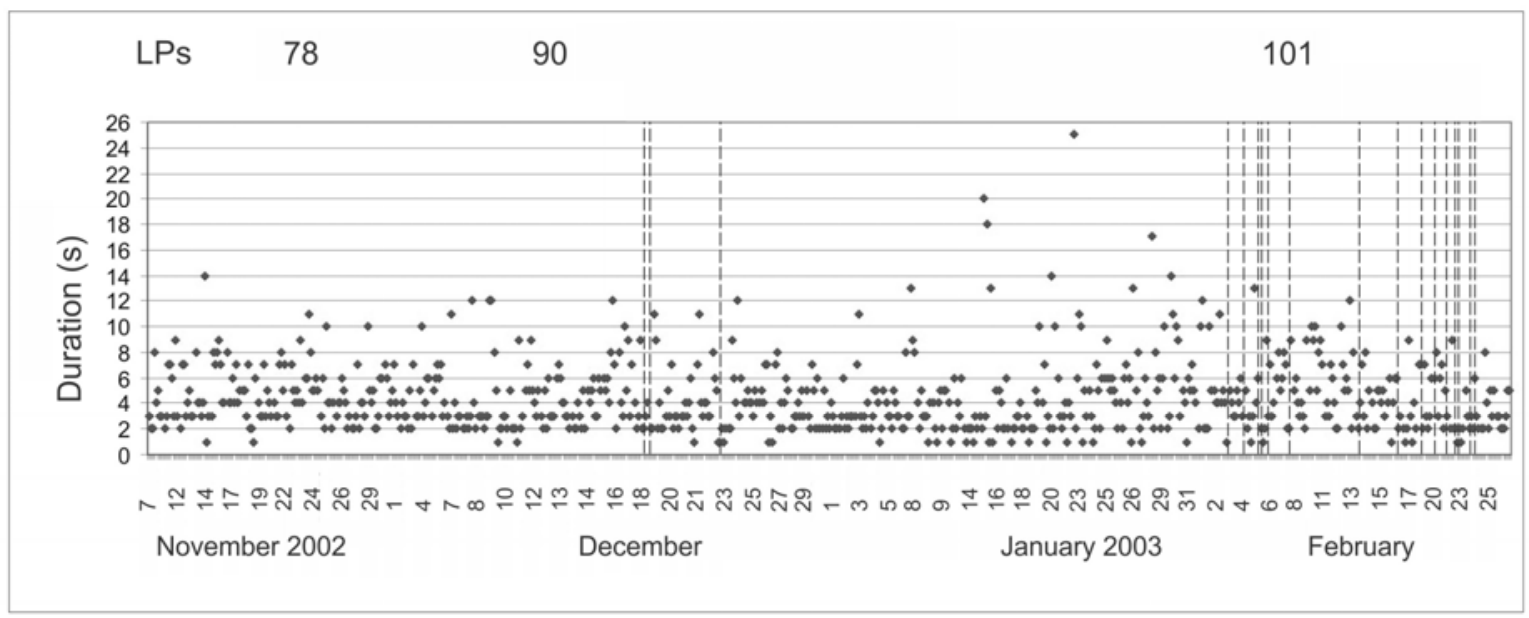

814

815

816 Quezada-Reyes_etal_Figure5.cdr

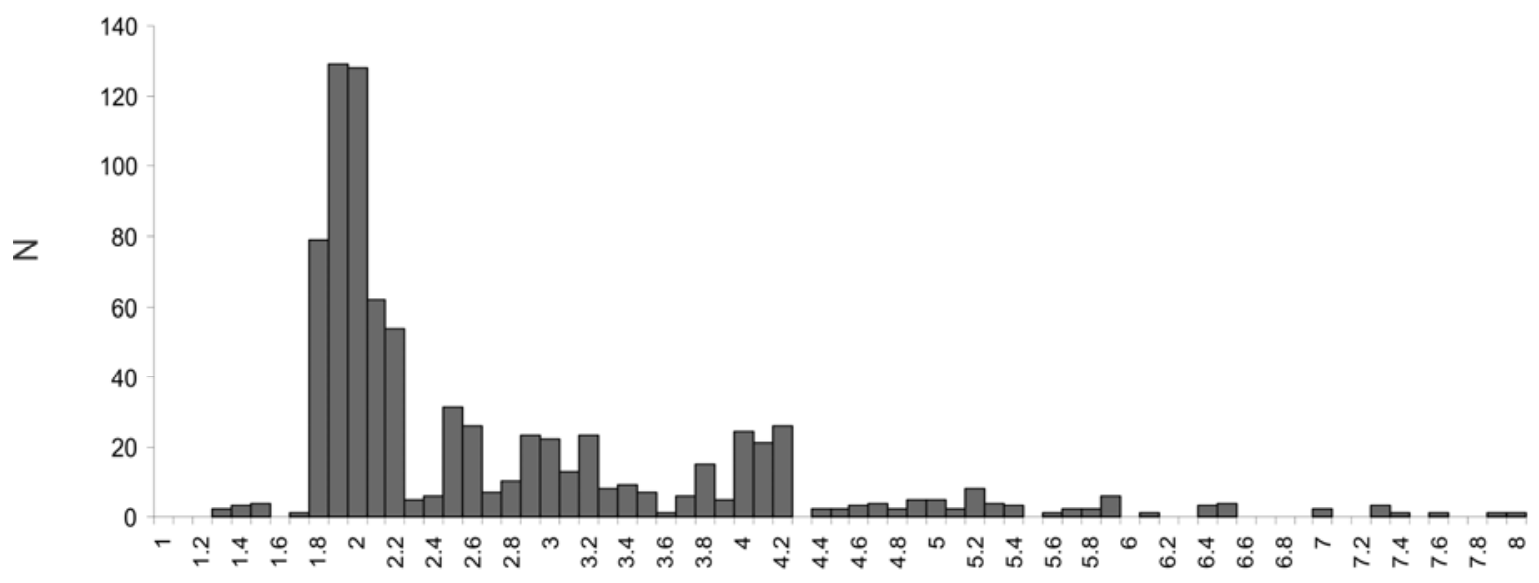

819 Quezada-Reyes_etal_Figure6.cdr 
821

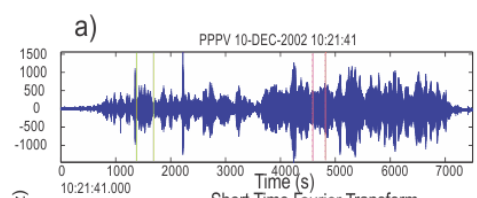

b)
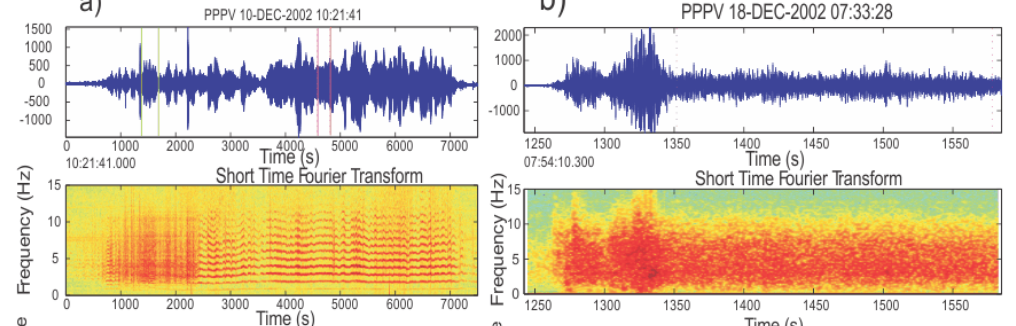

Time (s)

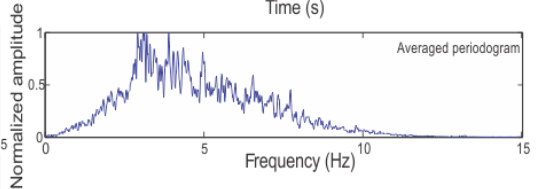

c)
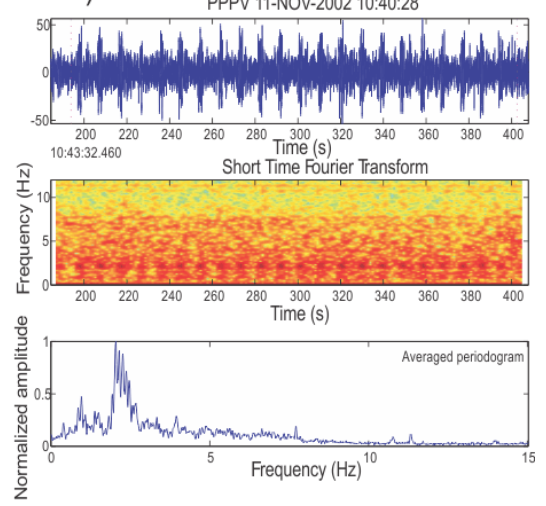

822

823 Quezada-Reyes_etal_Figure7.cdr 
a)

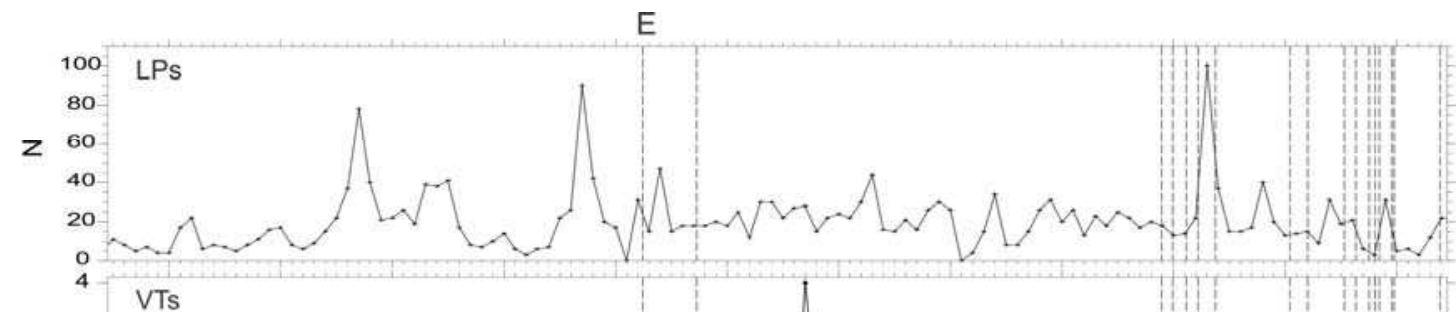

b)

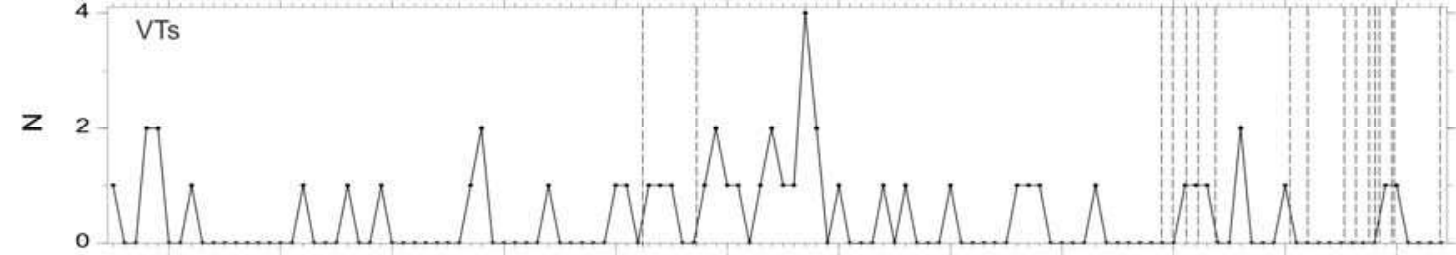

c)

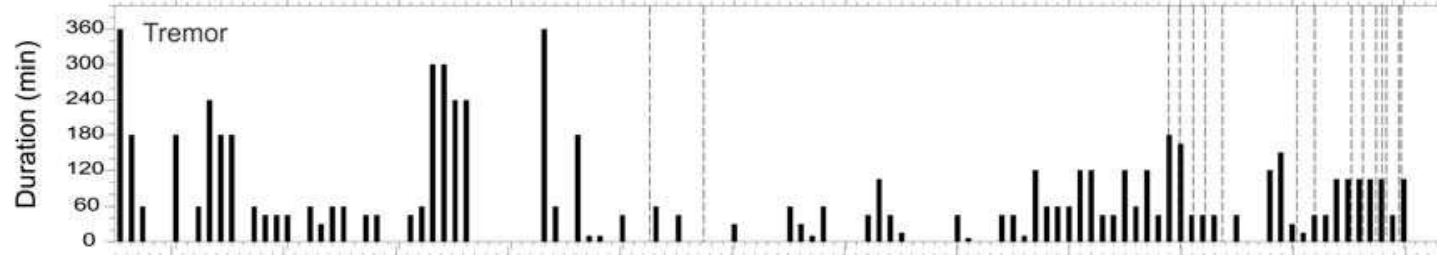

d)

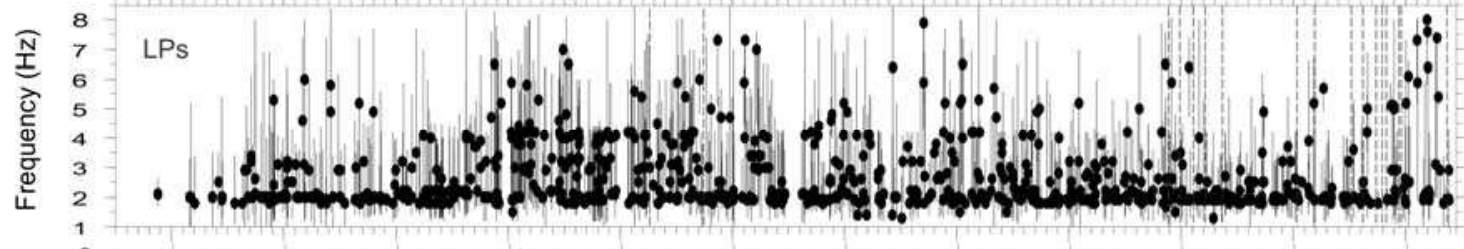

e)

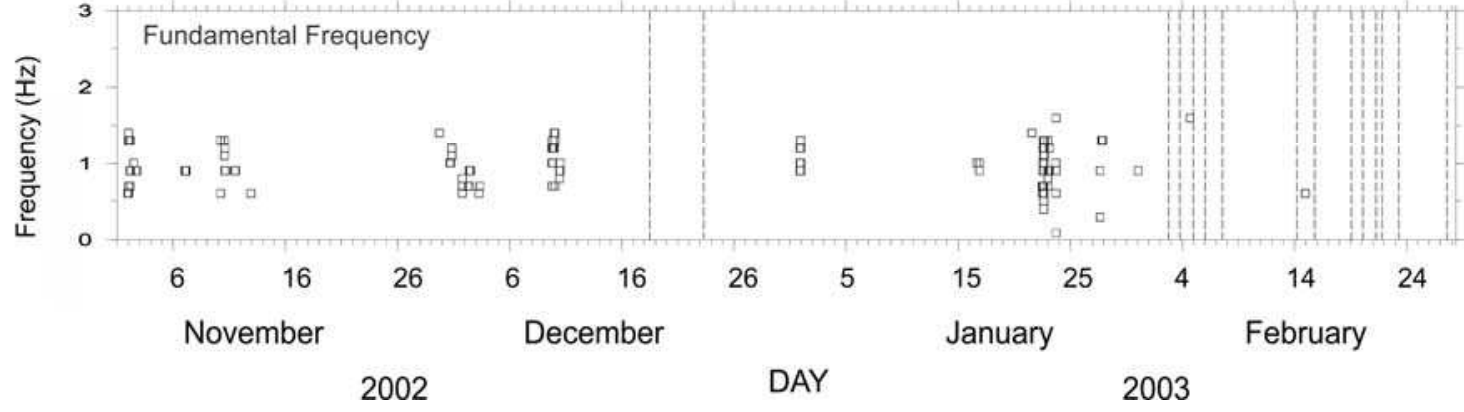

825

826

Quezada-Reyes_etal_Figure8.cdr

827

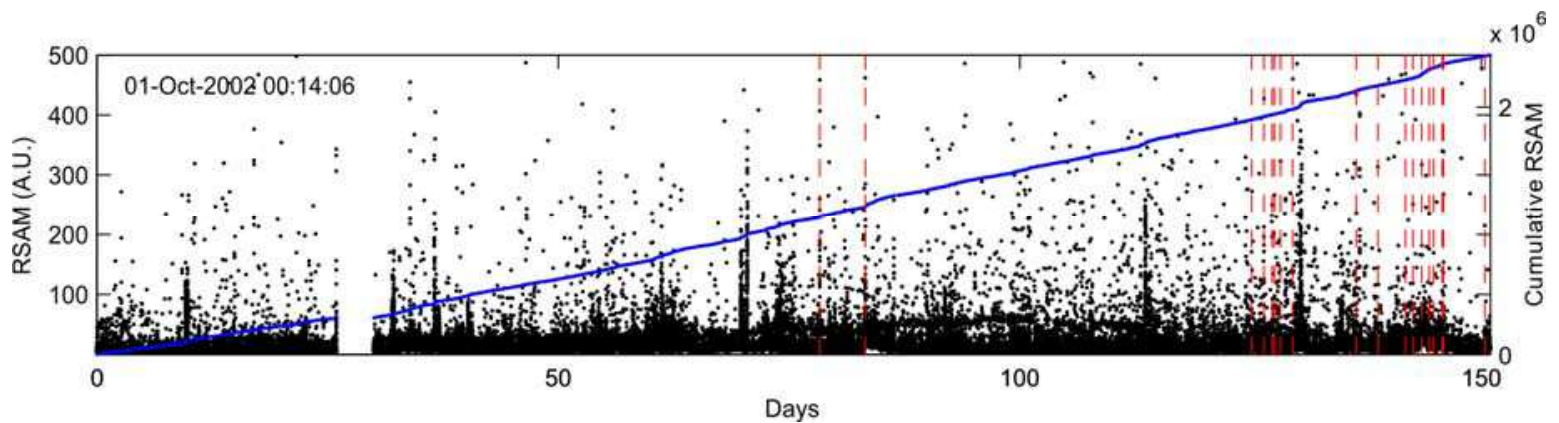



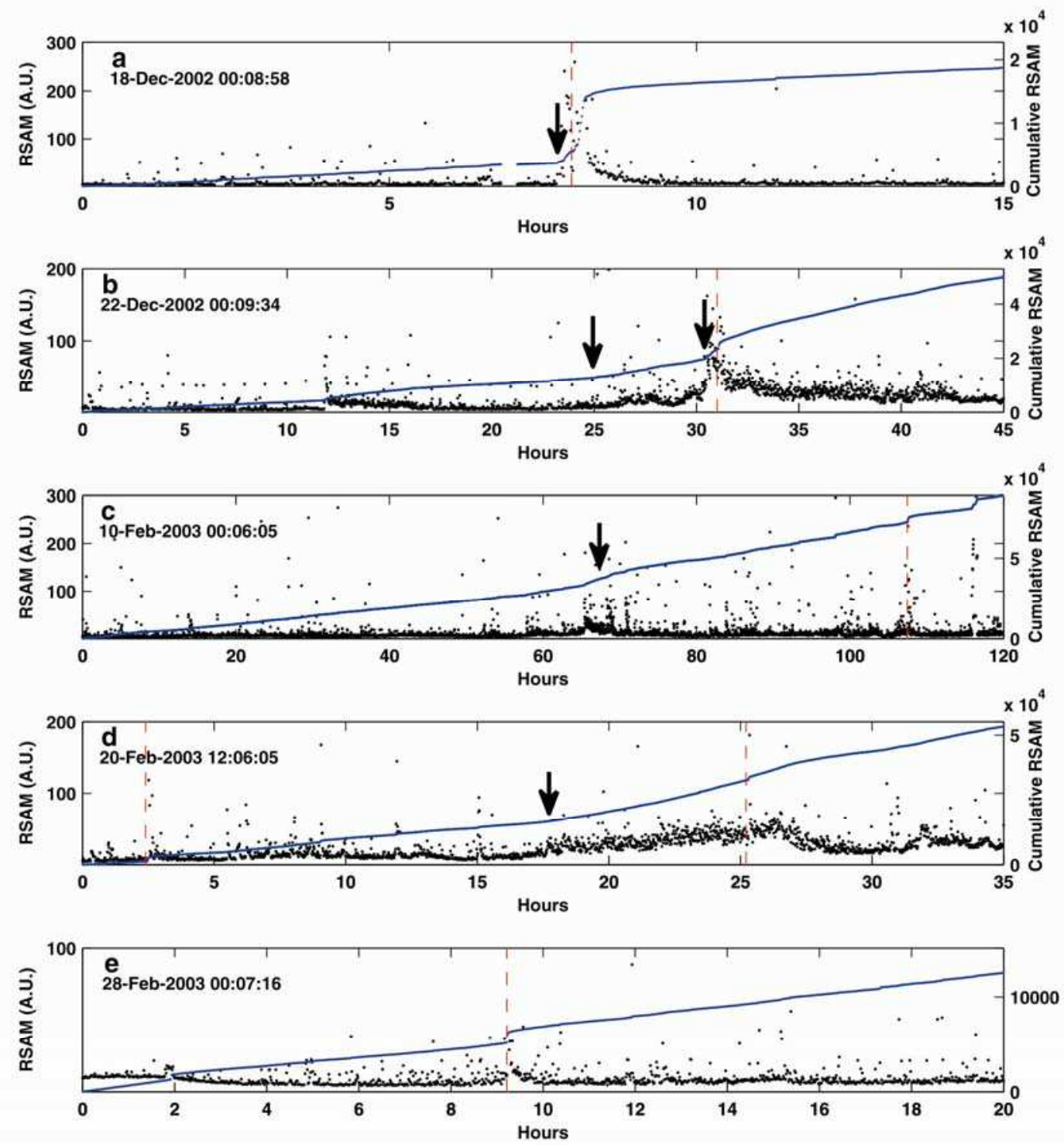

830

831

832 Quezada-Reyes_etal_Figure10.cdr 
PPPV 23-Dec-2002 06:04:04

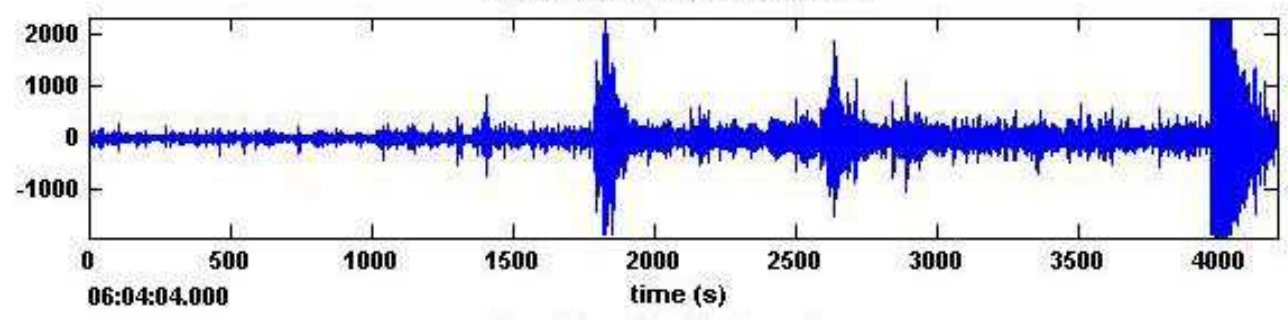

Short Time Fourier Transform

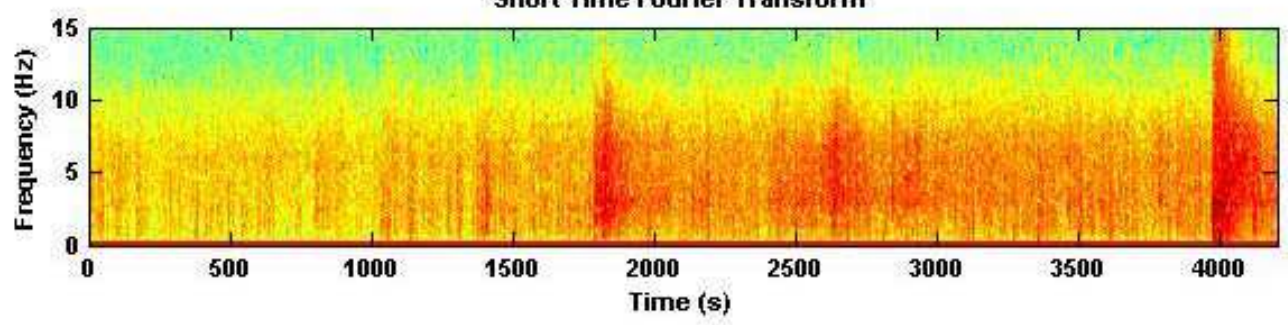

833

835 Quezada-Reyes_etal_Figure11.cdr

a)

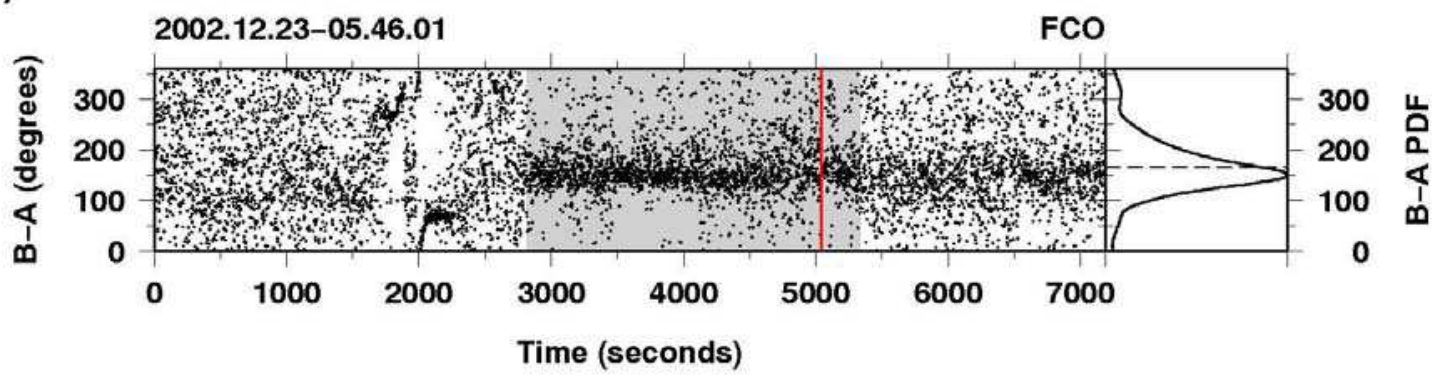

b)

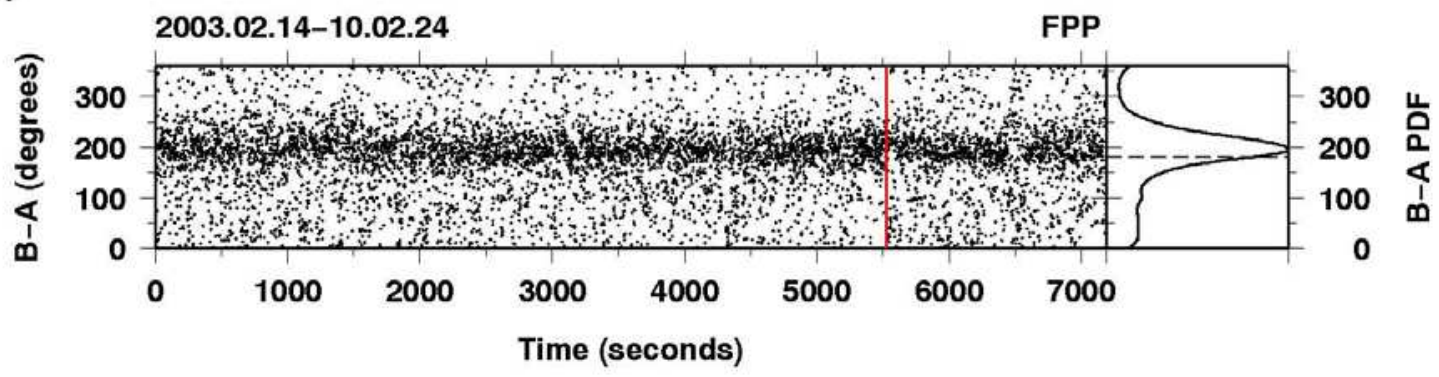

836

837

838 Quezada-Reyes_etal_Figure12.cdr 

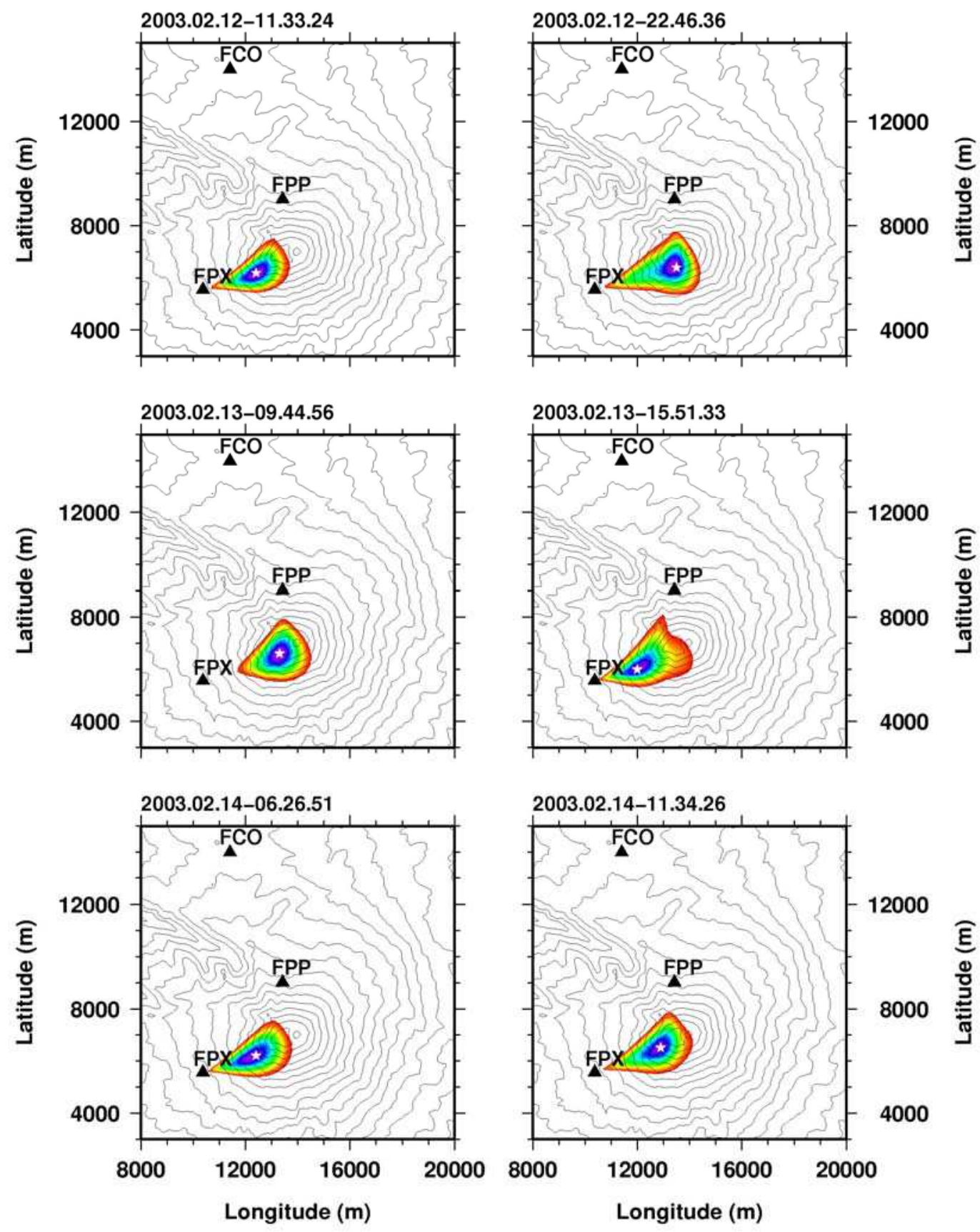

839

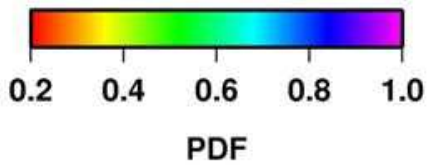

840

841 Table 1 


$\begin{array}{cccccccc}\begin{array}{c}\text { Date } \\ \text { Time }\end{array} & \text { E/e } & \text { Precursors } & \text { VLP } & \text { Mk } & \text { Ek } & \text { Duration } \\ \text { Dec. 18, 2002 } & 08: 07 & \text { E } & \text { Yes } & \text { Yes } & & 9,50 \mathrm{E}+07 & 540 \\ \text { Dec. 23, 2002 } & 07: 10 & \mathrm{E} & \text { Yes } & \text { Yes } & 2,4 & 6,70 \mathrm{E}+08 & 40 \\ \text { Feb. 3, 2003 } & 03: 07 & \text { e } & \text { No } & \text { No } & & 1,30 \mathrm{E}+06 & 210 \\ 4 & 10: 59 & \mathrm{E} & \text { Yes } & \text { Yes } & 2,9 & 1,20 \mathrm{E}+09 & 65 \\ 5 & 08: 35 & \text { e } & \text { No } & \text { No } & & 3,50 \mathrm{E}+05 & 180 \\ 5 & 14: 53 & \text { e } & \text { No } & \text { No } & & 3,00 \mathrm{E}+05 & 600 \\ 6 & 05: 56 & \mathrm{E} & \text { No } & \text { No } & & 2,70 \mathrm{E}+05 & 150 \\ 7 & 14: 00 & \text { e } & \text { No } & \text { Yes } & 1,4 & 9,40 \mathrm{E}+05 & 210 \\ 14 & 11: 34 & \mathrm{E} & \text { Yes } & \text { Yes } & 2,8 & 4,80 \mathrm{E}+08 & 80 \\ 16 & 19: 02 & \text { e } & \text { No } & \text { No } & & 1,20 \mathrm{E}+06 & 240 \\ 19 & 19: 20 & \text { e } & \text { No } & \text { Yes } & & 6,80 \mathrm{E}+05 & 430 \\ 20 & 14: 30 & \text { e } & \text { No } & \text { Yes } & & 6,30 \mathrm{E}+06 & 130 \\ 21 & 13: 19 & \text { e } & \text { Yes } & \text { No } & & 2,00 \mathrm{E}+06 & 190 \\ 22 & 08: 39 & \text { e } & \text { No } & \text { Yes } & 2,8 & 6,60 \mathrm{E}+08 & 100 \\ 22 & 20: 36 & \text { e } & \text { No } & \text { Yes } & 2,9 & 3,40 \mathrm{E}+08 & 135 \\ 23 & 19: 01 & \text { e } & \text { No } & \text { Yes } & 2,8 & 5,40 \mathrm{E}+08 & 80 \\ 23 & 22: 14 & \text { e } & \text { No } & \text { No } & & 7,50 \mathrm{E}+05 & 390 \\ 28 & 09: 15 & \mathrm{E} & \text { No } & \text { Yes } & & 1,60 \mathrm{E}+07 & 110\end{array}$

